\title{
KEABSAHAN PERJANJIAN PENGIKATAN JUAL BELI HAK ATAS TANAH YANG DIDASARKAN AKTA NOTARIS (STUDI KASUS PUTUSAN MAHKAMAH AGUNG NOMOR $130 \mathrm{~K} / \mathrm{PDT} / 2017$ )*
}

\author{
Oleh: \\ Putu Mahaesa Surya Putri Utami** \\ I Nyoman Suyatna*** \\ Program Kekhususan Hukum Bisnis \\ Fakultas Hukum Universitas Udayana
}

\begin{abstract}
ABSTRAK
Dalam masyarakat perjanjian pengikatan jual beli (PPJB) sering digunakan dalam pelaksanaan jual beli tanah. Seperti kasus jual beli tanah dengan perjanjian jual beli hak atas tanah yang terjadi di Banjar Padangtawang, Desa Canggu, Kecamatan Kuta Utara, Kabupaten Badung, Bali yang dibatalkan meskipun telah didasarkan akta pengikatan jual beli yang dibuat di hadapan Notaris. Permasalahan dalam jurnal ini membahas bagaimana latar belakang PPJB jual beli hak atas tanah itu dapat dikatakan sah dan bagaimana dasar pertimbangan Hakim Mahkamah Agung untuk membatalkan PPJB tersebut, yang bertujuan untuk mendapatkan pemahaman terkait keabsahan perjanjian pengikatan jual beli hak atas tanah tersebut. Metode penelitian dalam jurnal ini menggunakan penelitian hukum yuridis normatif, dengan pendekatan konsep dan perundang-undangan yang kemudian dikelompokkan secara sistematis. Hasil peneltian ini menjelaskan PPJB ini bermula saat I Rantuh, pemilik tanah sengketa membuat PPJB dengan Maria Nengah Suarti di kantor Notaris I Made Puryatma, S.H. dengan Akta Notaris Nomor 36, tanggal 9 November 1984, dikarenakan transaksi tersebut telah memenuhi syarat-syarat jual beli hak atas tanah sesuai ketentuan Pasal 37 ayat (1) Peraturan Pemerintah No. 24 Tahun 1997 tentang Pendaftaran Tanah maka PPJB Hak Atas Tanah tersebut

* Penulisan ini berjudul Keabsahan Perjanjian Pengikatan Jual Beli Hak atas Tanah yang didasarkan Akta Notaris (Studi Kasus Putusan Mahkamah Agung Nomor $130 \mathrm{~K} / \mathrm{Pdt} / 2017$ ), yang merupakan makalah ilmiah di luar ringkasan skripsi.

${ }^{* *}$ Penulis pertama dalam penulisan makalah ilmiah ini ditulis oleh Putu Mahaesa Surya Putri Utami, merupakan mahasiswa Fakultas Hukum Universitas Udayana. Korespondensi: putumahaesasuryaputri@gmail.com.

${ }^{* * *}$ Penulis kedua dalam penulisan makalah ilmiah ini ditulis oleh Dr. I Nyoman Suyatna, SH., MH., selaku Pembimbing Akademik dari penulis pertama di Fakultas Hukum Universitas Udayana.
\end{abstract}


dapat dikatakan legal (sah) menurut hukum. Namun, PPJB tersebut dapat dibatalkan atas dasar pertimbangan Hakim Mahkamah Agung dalam Putusan Kasasi Mahkamah Agung Nomor 130 K/Pdt/2017 tanggal 30 Maret 2017 bahwa: PPJB tersebut dibuat tanpa adanya kebebasan kehendak seperti ketentuan dalam Pasal 1320 KUH Perdata sehingga PPJB itu cacat secara hukum, serta pertimbangan bahwa perjanjian pengikatan jual beli tersebut telah kadaluarsa seperti dalam rumusan ketentuan Pasal 1381 KUH Perdata dan Pasal 1967 KUH Perdata.

\section{Kata Kunci: Keabsahan, Perjanjian Pengikatan Jual Beli, Hak Atas Tanah}

\section{ABSTRACT}

In a community of binding sale and purchase agreements (PPJB) is often used in the sale and purchase of land. As in the case of land purchase and purchase of land rights that occurred in Banjar Padangtawang, Canggu Village, North Kuta Sub-district, Badung Regency, Bali was canceled even though based on the deed of buying and selling made in the presence of Notary Public. The issue in this journal discusses how the background of PPJB on the sale of land rights can be said to be legitimate and how the Supreme Court judges consideration to cancel the PPJB, which aims to gain an understanding related to the legitimacy of the agreement to bind the sale and purchase of the land rights. The research method in this journal uses normative juridical legal research, with approach of concept and legislation which are then grouped systematically. The results of this study explain the PPJB started when I Rantuh, the owner of the land dispute made PPJB with Maria Nengah Suarti in the office of Notary I Made Puryatma, S.H. by Notarial Deed No. 36 dated November 9, year 1984, because the transaction has fulfilled the terms of sale and purchase of land rights pursuant to Article 37 paragraph (1) of Government Regulation Number 24 of 1997 concerning Land Registration then PPJB Land Rights can be said legal according to the applicable laws. However, such PPJB may be canceled on the basis of consideration of the Supreme Court Judge in the Supreme Court Decision Number 130 K / Pdt / 2017 dated March 30, year 2017 that: PPJB is made without any freedom of intention as stipulated in Article 1320 of Civil Code so that PPJB is legally defective, as well as the consideration that the sale and purchase binding agreement has expired as in the provisions of Article 1381 Civil Code and Article 1967 of Civil Code.

Keywords: Validity, Sale and Purchase Binding Agreement, Land Rights 


\section{PENDAHULUAN}

\subsection{Latar Belakang Masalah}

Bagi masyarakat Indonesia, tanah merupakan suatu asset penting yang memiliki fungsi sosial, serta merupakan akar sosio kultural, sehingga sering terjadi konflik, sengketa, maupun perselisihan terkait permasalahan pertanahan baik yang bersfat horizontal maupun vertikal dikarenakan keterbatasan dan tingginya kebutuhan manusia terhadap tanah. ${ }^{1}$ Pada tahun 2017, Data Konsorsium Pembaharuan Agraria (KPA) menunjukkan terjadinya sengketa agraria sebanyak 659 kasus dan salah satu sengketa yang paling sering terjadi adalah sengketa terkait jual beli tanah. Menurut Boedi Harsono, jual beli tanah merupakan suatu aktivitas jual beli yang ruang lingkup objeknya terbatas hanya pada hak milik atas tanah. ${ }^{2}$ Istilah jual beli tersebut diatur dalam peraturan perundang-undangan yang berkaitan dengan pertanahan, yaitu Undang-Undang No. 5 Tahun 1960, UndangUndang No. 16 Tahun 1985, Peraturan Pemerintah No. 24 Tahun 1997, Keputusan Presiden No. 55 Tahun 1993, Peraturan Presiden No. 36 Tahun 2005, dan Kepmen Agraria/Kepala BPN No. 21 Tahun 1994. ${ }^{3}$ Pengertian jual beli tanah menurut Pasal 1457 dan Pasal 1458 Burgerlijk Wetboek (BW) yaitu suatu persetujuan yang terjadi diantara kedua belah pihak untuk menyerahkan suatu kebendaan yang mana setelah mencapai kesepakatan tentang kebendaan tersebut dan harganya, meskipun benda itu belum diserahkan maupun harganya belum dibayar tetapi jual beli telah dianggap terjadi antara kedua belah pihak. ${ }^{4}$ Sedangkan, khusus

${ }^{1}$ Bernhard Limbong, 2014, Opini Kebijakan Agraria, cet. I, PT Dharma Karsa Utama, Jakarta, h. i.

2 Urip Santoso, 2014, Pendaftaran dan Peralihan Hak Atas Tanah, cet. IV, Kencana Prenada Media Group, Jakarta, h. 360.

${ }^{3}$ Ibid, h. 359.

${ }^{4}$ Ibid, h. 362. 
jual beli tanah yang diatur dalam Overschrijving Ordonnantie Stb. 1934 Nomor 27 terdapat dua perbuatan hukum, yaitu: Perjanjian jual beli tanah dibuat dengan akta notaris atau akta di bawah tangan (yang pada saat itu belum terjadi pemindahan hak atas tanah dari penjual kepada pembeli) dan Penyerahan yuridis diselenggarakan dengan pembuatan akta balik nama di muka dan oleh Kepala Kantor Pendaftaran Tanah selaku Overschrijvings Ambtenaar (pada saat inilah terjadi pemindahan hak atas tanah dari penjual kepada pembeli). ${ }^{5}$ Berarti, dalam pelaksanaan jual beli tanah didahului dengan adanya perjanjian jual beli baru setelah itu dilakukan penyerahan yuridis hak atas tanah tersebut.

Jual beli hak atas tanah yang dilakukan hanya dengan selembar kwitansi saja akan menimbulkan kesulitan-kesulitan di pihak pembeli saat ia hendak mendaftarkan tanahnya atau melakukan balik nama hak atas tanah yang dibelinya, sehingga akibatnya dapat merugikan pihak-pihak yang terlibat dalam jual beli hak atas tanah tersebut dan dengan adanya masalah tersebut maka dibuatlah Akta Pengikatan Jual Beli (PJB). Hingga kini tidak ada pengaturan yang jelas terkait PPJB tersebut dalam peraturan perundang-undangan, sehingga sering kali dipertanyakan mengenai bagaimana keabsahan dari PPJB hak atas tanah tersebut. Terkait uraian tersebut, saya tertarik untuk membahas masalah terkait kegiatan jual beli tanah dengan perjanjian pengikatan jual beli yang dibuat di hadapan Notaris yang secara khusus akan membahas salah satu kasus jual beli tanah dengan perjanjian jual beli hak atas tanah yang terjadi di Banjar Padangtawang, Desa Canggu, Kecamatan Kuta Utara, Kabupaten Badung, Bali yang perkaranya telah diputus oleh Pengadilan Negeri Denpasar dengan Putusan Nomor 661/Pdt.G/2015/PN 
Dps, kemudian dikuatkan dengan Putusan Pengadilan Tinggi Denpasar Nomor 71/PDT/2016/PT.DPS., serta dilanjutkan pada tingkat kasasi Mahkamah Agung dengan Putusan Mahkamah Agung Republik Indonesia Nomor 130 K/Pdt/2017.

\subsection{Rumusan Masalah dan Tujuan Penulisan}

1. Bagaimanakah keabsahan dari Perjanjian Pengikatan Jual Beli (PPJB) Hak Atas Tanah yang dibuat berdasarkan Akta Notaris Nomor 36, tanggal 9 November 1984 di Banjar Padangtawang, Desa Canggu, Kecamatan Kuta Utara, Kabupaten Badung, Bali?

2. Apakah dasar pertimbangan Hakim Mahkamah Agung sudah benar untuk membatalkan PPJB yang dibuat berdasarkan Akta Notaris dalam Putusan Mahkamah Agung Republik Indonesia Nomor $130 \mathrm{~K} / \mathrm{Pdt} / 2017$ dikaitkan dengan asas perjanjian yang ada?

Penulisan jurnal ini bertujuan untuk menganalisis Putusan Mahkamah Agung Republik Indonesia Nomor 130 K/Pdt/2017 yang membatalkan Perjanjian Pengikatan Jual Beli tersebut.

\section{ISI MAKALAH}

\subsection{Metode Penelitian}

\subsubsection{Jenis Penelitian}

Jenis penelitian yang digunakan untuk mengkaji permasalahan mengenai keabsahan PPJB tersebut, termasuk dalam penelitian hukum yuridis normatif, yang nantinya akan menganalisis dan menjelaskan bahwa terdapat sebuah PPJB hak atas tanah yang telah diakui keabsahannya berdasarkan adanya Akta Notaris Nomor 36, tanggal 9 November 1984, sesuai dengan ketentuan Pasal 37 ayat (1) PP No. 24 Tahun 1997. Namun, PPJB tersebut dapat saja dibatalkan sekalipun didasarkan dengan Akta Notaris, apabila ditemukan adanya syarat-syarat perjanjian yang 
cacat hukum, seperti halnya dalam Putusan Kasasi Mahkamah Agung Nomor 130 K/Pdt/2017 tanggal 30 Maret 2017 yang membatalkan perjanjian pengikatan jual beli hak atas tanah yang terjadi di Banjar Padangtawang, Desa Canggu, Kecamatan Kuta Utara, Kabupaten Badung, Bali.

\subsubsection{Jenis Pendekatan}

Peneliti dalam penulisan jurnal ini mempergunakan pendekatan perundang-undangan (statute approach) dikarenakan perundang-undangan merupakan produk beschikking/atau decree yang bersifat kongkret dan khusus, kemudian digunakan pendekatan konsep (concevtual approach) disebabkan dari adanya bahan hukum yang diperoleh dari pendekatan perundangundangan dilakukan inventarisasi dalam menemukan konsep sebagai acuan dalam mengkaji perasalahan jual beli tanah tersebut, dan pendekatan kasus (case approach) yang kajian pokoknya terkait pertimbangan-pertimbangan pengadilan hingga memutus Putusan Mahkamah Agung Republik Indonesia Nomor $130 \mathrm{~K} / \mathrm{PDT} / 2017$ tanggal 30 Maret 2017.

\subsubsection{Sumber Bahan Hukum}

1. Bahan Hukum Primer

Bahan Hukum Primer dalam penelitian ini diperoleh melalui peraturan perundang-undangan seperti UUD NRI Tahun 1945, KUH Perdata, Undang-Undang RI No. 5 Tahun 1960 tentang Peraturan Dasar Pokok-Pokok Agraria, PP No. 24 Tahun 1997 tentang Pendaftaran Tanah, dan PP No. 37 Tahun 1998 tentang Peraturan Jabatan Pembuat Akta Tanah (PPAT).

2. Bahan Hukum Sekunder

Bahan Hukum Sekunder dalam penelitian ini diperoleh berdasarkan Putusan Pengadilan terkait kasus 
PPJB tersebut yakni Putusan Pengadilan Negeri Denpasar Nomor 661/Pdt.G/2015/PN Dps, kemudian Putusan Pengadilan Tinggi Denpasar Nomor 71/PDT/2016/PT.DPS. dan Putusan Mahkamah Agung Nomor 130 K/Pdt/2017 serta didukung dengan hasil karya ilmiah dan penelitianpenelitian di bidang PPJB tersebut.

3. Bahan Hukum Tersier

Bahan Hukum Tersier yang dipergunakan dalam jurnal ini berupa bahan pustaka, jurnal, surat kabar dan majalah terkait permasalahan dalam jurnal ini.

\subsubsection{Teknik Pengumpulan Bahan Hukum}

Teknik pengumpulan bahan hukum yang digunakan adalah dengan metode sistematis dengan melakukan analisis dan mengkaji peraturan perundang-undangan, berbagai literatur serta dengan mempergunakan informasi dari Bapak I Made Sepud selaku pengacara yang manangani kasus tersebut.

\subsubsection{Teknik Pengolahan dan Analisis Bahan Hukum}

Bahan hukum yang diperoleh kemudian diolah dan dianalisis dengan teknik analisa kualitatif. Kemudian disajikan secara deskriptif sistematis sesuai dengan pedoman penulisan jurnal di Fakultas Hukum Universitas Udayana.

\subsection{Hasil Penelitian dan Pembahasan}

\subsubsection{Keabsahan Perjanjian Pengikatan Jual Beli Hak Atas}

Tanah yang dibuat Berdasarkan Akta Notaris Nomor 36, Tanggal 9 November 1984 di Banjar Padangtawang, Desa

Canggu, Kecamatan Kuta Utara, Kabupaten Badung, Bali

Perbuatan hukum jual beli hak atas tanah didahulukan dengan adanya perjanjian jual beli yang bersifat riil dengan adanya penyerahan yuridis berupa pembuatan akta balik nama oleh Kepala Kantor Pendaftaran Tanah atas tanah yang diperjanjikan 
sebagai syarat mutlak perjanjian jual beli tanah tersebut sesuai ketentuan Pasal 1457 sampai Pasal 1540 KUH Perdata. Perjanjian pengikatan jual beli (PPJB) hak atas tanah dimaksudkan untuk memberikan kepastian hukum pada pihak-pihak yang melakukan perbuatan hukum jual beli hak atas tanah tersebut dengan senantiasa mengacu atau terikat dengan adanya ketentuan peraturan perundang-undangan di bidang pertanahan seperti UUD NRI Tahun 1945, Kitab Undang-Undang Hukum Perdata, Undang-Undang RI No. 5 Tahun 1960 tentang Peraturan Dasar Pokok-Pokok Agraria dan beberapa peraturan pemerintah yang mendukung pelaksanaan undang-undang tersebut.

Mengenai kasus ini bermula saat I Rantuh (almarhum), seorang petani yang tinggal di Banjar Padangtawang, Desa Canggu, Kecamatan Kuta, Kabupaten Badung, Bali (yang merupakan tanah sengketa), merupakan pemilik tanah yang menguasai sendiri sebidang tanah waris hak milik dengan pipil nomor 269, persil nomor 12, klas I, dengan luas kurang lebih 2050 $\mathrm{m}^{2}$ (dua ribu lima puluh meter persegi) yang mana ia hidup sendiri tanpa adanya keturunan. Saat I Rantuh masih hidup ia sempat membuat Perjanjian Pengikatan Jual Beli (PPJB) dengan Maria Nengah Suarti di kantor Notaris I Made Puryatma, S.H. dengan Akta Notaris Nomor 36, tanggal 9 November 1984. Dalam akta tersebut telah memuat ketentuan bahwa perjanjian tersebut tetap berlaku dan dapat diteruskan sekalipun salah satu pihak meninggal sebelum akta jual beli tersebut dilakukan, yang mana berlaku antara pihak yang masih hidup dengan ahli waris dari pihak yang meninggal dunia, atau antara sesama ahli waris bila kedua pihak telah meninggal. Kemudian terjadi penyerahan tanah tersebut kepada Maria Nengah Suarti setelah ia membayar Rp. 2.050.000,- kepada I Rantuh dan sejak penandatanganan akta 
tersebut maka kegiatan jual beli hak atas telah terjadi. Dikarenakan transaksi tersebut dilakukan secara kontan terang dan tunai serta telah memenuhi syarat-syarat jual beli hak atas tanah maka seharusnya perjanjian jual beli tersebut dapat dinyatakan legal (sah) secara hukum.

Dasar keberlakuan Undang-Undang RI No. 5 Tahun 1960 tentang Peraturan Dasar Pokok-Pokok Agraria adalah ketentuan Pasal 19 PP No. 10 Tahun 1961 yang telah menjadi Pasal 37 ayat (1) PP No. 24 Tahun 1997 jo Pasal 2 Peraturan Kepala BPN Nomor 7 Tahun 2007 menentukan setiap perjanjian yang menyangkut hak atas tanah baik berupa pengalihan hak atas tanah, peminjaman uang dengan hak atas tanah sebagai jaminan, pemberian hak baru atas tanah haruslah didasarkan dengan suatu akta yang dibuat dihadapan PPAT atau Notaris. ${ }^{6}$ Pengalihan hak atas tanah dapat dikatakan legal (sah) dan dapat didaftarkan balik nama apabila PPAT sebagai pejabat umum menyaksikan dan mencatat segala perbuatan hukum dalam pembuatan akta jual beli tersebut, sehingga dengan adanya akta PPAT dapat memberikan status baru berdasarkan permohonan balik nama yang telah dimohonkan pihak yang menerima pengalihan hak. ${ }^{7}$ Adanya syarat bahwa dalam pembuatan akta jual beli hak atas tanah harus dilakukan di hadapan PPAT dikarenakan guna legalitas (keabsahan) dari perjanjian-perjanjian yang terkait dengan jual beli hak atas tanah tersebut.

Mengenai syarat formal bahwa jual beli hak atas tanah harus dibuktikan dengan adanya akta PPAT telah diatur dalam ketentuan Pasal 37 ayat (1) PP No. 24 Tahun 1997. Namun, tidak

${ }^{6}$ Herlien Budiono, 2006, Asas Keseimbangan Bagi Hukum Perjanjian Indonesia Hukum Perjanjian Berlandaskan Asas-Asas Wigati Indonesia, PT. Citra Aditya Bakti, Bandung, h. 257.

7 Muhammad Yamin Lubis dan Abd. Rahim Lubis, 2008, Hukum Pendaftaran Tanah, Mandar Maju, Bandung, h. 121. 
mutlak harus dibuktikan dengan akta PPAT, sesuai dengan ketentuan Pasal 37 ayat (2) PP No. 24 Tahun 1997 Kepala Kantor Pertanahan Kabupaten/atau Kota dapat melakukan pendaftaran pemindahan hak atas tanahnya meskipun tanpa adanya akta PPAT. 8 Adanya dasar akta jual beli yang dibuat oleh PPAT, maka pada saat itu terjadi pemindahan hak atas tanah dari pemegang haknya sebagai penjual kepada pihak lain sebagai pembeli, kemudian aktifitas jual beli tersebut harus didaftarkan ke Kantor Pertanahan Kabupaten/atau Kota setempat. ${ }^{9}$ Sehingga, PPJB hak atas tanah yang terjadi antara I Rantuh dengan Maria Nengah Suarti dikatakan legal (sah) didasarkan dengan adanya Akta Notaris Nomor 36, tanggal 9 November 1984 yang dibuat di Kantor Notaris I Made Puryatma, S.H.

\subsubsection{Dasar Pertimbangan Hakim Mahkamah Agung Sudah Benar untuk Membatalkan PPJB Hak Atas Tanah yang dibuat Berdasarkan Akta Notaris dalam Putusan Mahkamah Agung Republik Indonesia Nomor 130 K/Pdt/2017 dikaitkan dengan Asas Perjanjian yang Ada}

Perjanjian Pengikatan Jual Beli (PPJB) dapat saja dibatalkan apabila kemudian hari ditemukan adanya syarat-syarat perjanjian yang cacat hukum, bentuk nyata pembatalan perjanjian tersebut dapat dilihat dalam Putusan Pengadilan Tinggi Denpasar Nomor 71/Pdt/2016/PT.Dps tanggal 26 Juli 2016 diperkuat dengan Putusan Kasasi Mahkamah Agung Nomor 130 K/Pdt/2017 tanggal 30 Maret 2017 yang membatalkan perjanjian pengikatan jual beli hak atas tanah yang terjadi di Banjar Padangtawang, Desa Canggu, Kecamatan Kuta Utara, Kabupaten Badung, Bali sekalipun didasarkan dengan adanya Akta Notaris Nomor 36, tanggal 9 November 1984. Analisis pertimbangan hakim

8 Urip Santoso, op.cit, h. 369.

9 Ibid, h. 371. 
Mahkamah Agung dalam memutus Putusan Kasasi Mahkamah Agung Nomor $130 \mathrm{~K} / \mathrm{Pdt} / 2017$ adalah sebagai berikut:

Pertimbangan Hakim Mahkamah Agung yang pertama menyatakan bahwa PPJB atas objek sengketa antara I Rantuh dengan orang tua Para Pemohon Kasasi dibuat ketika I Rantuh berada dalam usia tua dan dalam keadaan sakit, serta berada dalam perawatan orang tua Para Pemohon Kasasi sebagai pembeli, sehingga benar bahwa I Rantuh sebagai penjual tidak memiliki kebebasan kehendak, karena itu Pengikatan Jual Beli atas objek sengketa dalam perkara a quo adalah cacat secara hukum sesuai ketentuan Pasal 1320 KUH Perdata. Maka, Putusan Mahkamah Agung Republik Indonesia Nomor 130 K/Pdt/2017 sudah benar telah menolak permohonan kasasi dari pihak terbanding (I Wayan Sarjana Tarsisius, I Nyoman Sarwadi, Paulus I Wayan Puryadi, Carolus I Nyoman Mariadi, dan Stefanus I Made Sartika) karena apabila dilihat dari asas kebebasan kontrak yang tercermin dalam ketentuan Pasal 1338 ayat (1) KUH Perdata menentukan bahwa semua persetujuan yang dibuat secara sah berlaku sebagai undang-undang bagi mereka yang membuatnya serta memberi kebebasan bagi para pihak untuk membuat atau tidak membuat perjanjian, mengadakan perjanjian dengan siapapun, menentukan isi perjanjian, dan menentukan bentuk perjanjian. Maka, disimpulkan bahwa tidak dipenuhinya asas tersebut dikarenakan kesepakatan itu dibuat saat I Rantuh dalam keadaan sakit dan berada dalam tekanan sehingga tidak dapat memberikan kesepakatan secara bebas, berarti alasan-alasan tersebut menjadi alasan pembenar Mahkamah Agung membatalkan PPJB tersebut sebab perjanjian itu bertentangan ketentuan Pasal 1320 KUH Perdata yang telah mengatur bahwa sahnya perjanjian harus menganut tiga asas penting yang terdapat dalam hukum perikatan 
yaitu10 asas kebebasan berkontrak, asas konsensual dan asas pacta sunt servanda serta syarat-syarat seperti adanya kesepakatan (toesteming) para pihak, kecakapan melakukan perbuatan hukum, adanya objek tertentu (onderwerp der overeenskomst), dan adanya sebab yang halal (geoorloofde oorzak).

Apabila dalam sebuah perjanjian melanggar syarat obyektif yaitu hal tertentu/atau suatu sebab yang halal, maka perjanjian tersebut "batal demi hukum", sedangkan apabila melanggar syarat subyektif, yaitu kesepakatan untuk mengikatkan dirinya atau kecapakan untuk melakukan perbuatan hukum, maka perjanjian tersebut "dapat dibatalkan". Berdasarkan pada pertimbangan tersebut, karena dalam PPJB tersebut tidak terpenuhinya syarat subjektif perjanjian yaitu kesepakatan para pihak untuk mengikatkan dirinya sesuai ketentuan Pasal 1320 KUH Perdata, maka akibat hukumnya PPJB hak atas tanah yang terjadi antara I Rantuh dengan Maria Nengah Suarti yang didasarkan dengan adanya Akta Notaris Nomor 36, tanggal 9 November 1984 cacat secara hukum, yang berarti Akta Notaris tersebut tidak sah dan dapat dibatalkan. Akibat hukum dari pembatalan Perjanjian Pengikatan Jual Beli (PPJB) tersebut, adalah PPJB tersebut berakhir dan sepanjang perlu kedua belah pihak dapat melepaskan diri dari apa yang ditetapkan dalam ketentuan Pasal 1266 dan Pasal 1267 KUH Perdata. Pihak penjual wajib mengembalikan uang yang telah dibayarkan pihak pembeli setelah dipotong beberapa persen dari harga jual tanah dan bangunan tersebut. Pengembalian uang tersebut dilakukan selambatlambatnya dalam jangka waktu tertentu yang telah disepakati.

Pertimbangan lainnya bahwa Akta PPJB Nomor 36 tertanggal 9 November 1984, sementara surat gugatan atas kasus

10 R. Wirjono Prodjodikoro, 2000, Azas-azas Hukum Perjanjian, Mandar Maju, Bandung, h. 14-15. 
tersebut terdaftar tertanggal 26 Agustus 2015 di Kepaniteraan Pengadilan Negeri Denpasar dibawah register perkara perdata Nomor 611/Pdt.G/2015/PN Dps, berarti perjanjian pengikatan jual beli tersebut dapat berakhir/atau bebas dari perikatan dikarenakan telah lewat waktu atau kadaluarsa seperti rumusan ketentuan Pasal 1381 dan Pasal 1967 KUH Perdata karena telah lewat batas waktu tiga puluh tahun tuntutan hukum dapat hapus karena kadaluarsa.

Maka saya sependapat dengan Mahkamah Agung, bahwa perjanjian itu memang dapat dibatalkan sebab melihat pada analisis pertimbangan hukum di atas, ternyata putusan Pengadilan Tinggi Denpasar dalam perkara ini tidak bertentangan dengan hukum dan/atau undang-undang, maka permohonan kasasi yang diajukan oleh para pemohon kasasi harus ditolak. Kemudian, terkait dengan upaya hukum lainnya yang dapat dilakukan oleh I Wayan Sarjana Tarsisius dan kawan-kawan terhadap Putusan Mahkamah Agung Nomor 130 K/Pdt/2017 yang telah mempunyai kekuatan hukum tetap adalah dengan melakukan upaya hukum luar biasa yaitu Peninjauan Kembali (request civil) ke Mahkamah Agung dengan mengikuti ketentuanketentuan pada Pasal 67 Undang-Undang Nomor 5 Tahun 2004 tentang Mahkamah Agung.

\section{PENUTUP}

\subsection{Kesimpulan}

1. Kasus PPJB ini bermula saat I Rantuh, pemilik tanah di Banjar Padangtawang, Desa Canggu, Kecamatan Kuta, Kabupaten Badung, Bali membuat Perjanjian Pengikatan Jual Beli (PPJB) dengan Maria Nengah Suarti di kantor Notaris I Made Puryatma, S.H. dengan Akta Notaris Nomor 36, tanggal 9 November 1984, dikarenakan transaksi 
tersebut telah memenuhi syarat formal jual beli hak atas tanah yang harus dibuktikan dengan adanya akta PPAT sesuai ketentuan Pasal 37 ayat (1) PP No. 24 Tahun 1997 maka PPJB hak atas tanah yang terjadi antara I Rantuh dengan Maria Nengah Suarti dapat dikatakan legal (sah) menurut hukum.

2. Dalam Putusan Kasasi Mahkamah Agung Nomor 130 K/Pdt/2017 tanggal 30 Maret 2017 yang membatalkan PPJB hak atas tanah tersebut sekalipun didasarkan adanya Akta Notaris, dengan pertimbangan Hakim Mahkamah Agung antara lain: PPJB tersebut dibuat tanpa adanya kebebasan kehendak seperti ketentuan dalam Pasal 1320 KUH Perdata sehingga perjanjian pengikatan jual beli hak atas tanah sengketa dalam perkara a quo adalah cacat secara hukum, serta PPJB tersebut telah lewat waktu atau kadaluarsa seperti dalam rumusan ketentuan Pasal 1381 KUH Perdata Pasal 1967 KUH Perdata berarti perjanjian pengikatan jual beli tersebut dapat berakhir/atau bebas dari perikatan sehingga PPJB dapat dibatalkan.

\subsection{Saran}

Seharusnya dalam pembuatan akta PPJB tersebut diharapkan agar para Notaris, pejabat PPAT, maupun masyarakat wajib membuat ketentuan-ketentuan yang lebih jelas, tegas dan terperinci terkait klausul-klausul dan perbuatan-perbuatan lainnya yang mungkin terjadi dalam PPJB tersebut. Serta, perlu adanya pengaturan yang lebih kompleks terkait PPJB hak atas tanah khususnya dalam Undang-Undang RI No. 5 Tahun 1960 tentang Peraturan Dasar Pokok-Pokok Agraria sehingga nantinya dapat mempertahankan status dan kedudukan dari PPJB tersebut. 


\section{Buku}

\section{DAFTAR PUSTAKA}

Budiono, Herlien, 2006, Asas Keseimbangan Bagi Hukum Perjanjian Indonesia, PT. Citra Aditya Bakti, Bandung.

Harsono, Boedi, 2008, Hukum Agraria Indonesia: Sejarah Pembentukan Undang-undang Pokok Agraria, Isi dan Pelaksanaannya, cet. XII, Djambatan, Jakarta.

Hutagulung, Arie S., et. al., 2012, Hukum Pertanahan di Belanda dan di Indonesia, Seri Penusunan Negara Hukum, Pustaka Larasan, Denpasar.

Limbong, Bernhard, 2014, Opini Kebijakan Agraria, cet. I, PT Dharma Karsa Utama, Jakarta.

Lubis, Muhammad Yamin dan Abd. Rahim Lubis, 2008, Hukum Pendaftaran Tanah, Mandar Maju, Bandung.

Santoso, Urip, 2014, Pendaftaran dan Peralihan Hak Atas Tanah, cet. IV, Kencana Prenada Media Group, Jakarta.

Sodiki, Achmad, 2012, Politik Hukum Agraria, cet. I, Konstitusi Press, Jakarta.

\section{Jurnal Ilmiah}

Jayanti, Ni Made Utami, I Nyoman Darmadha dan A. A. Sri Indrawati, 2016, "Batalnya Pengikatan Perjanjian Jual Beli Tanah dan Bangunan Karena Perbuatan Melawan Hukum yang dilakukan Oleh PT. Srikandi”, Jurnal Kerta Semaya Fakultas Hukum Universitas Udayana, Volume 04, Nomor 02, Februari, Denpasar.

Sari, Luh Putu Novita dan I Made Arya Utama, 2018, "Perbandingan Kekuatan Hukum Akta Pengikatan Jual Beli Hak Atas Tanah yang dilakukan dihadapan Notaris dengan di Bawah Tangan", Jurnal Kerta Semaya Fakultas Hukum Universitas Udayana, Volume 06, Nomor 02, Maret, Denpasar.

\section{Peraturan Perundang-Undangan}

Kitab Undang-Undang Hukum Perdata.

Republik Indonesia, Undang-Undang Nomor 5 Tahun 1960 tentang Peraturan Dasar Pokok-Pokok Agraria, LN RI Tahun1960 No. 104, TLN No. 2043.

, Peraturan Pemerintah Nomor 24 Tahun 1997 tentang Pendaftaran Tanah (LN RI Tahun 1997 No. 59, TLN RI No. 3696).

, Peraturan Pemerintah Nomor 37 Tahun 1998 tentang Peraturan Jabatan Pembuat Akta Tanah (PPAT) (LN RI Tahun 1998 No. 52, TLN RI No. 3746). 